\title{
Distance Learning's (PJJ) Strategies In Islamic Religious Education by using Online Learning (Case study at SMK Negeri 2 Salatiga)
}

\author{
Ainun Jariyah \\ IAIN Salatiga, Salatiga, Indonesia \\ ainunjariyah05@gmail.com \\ Mukh Nursikin \\ IAIN Salatiga, Salatiga, Indonesia \\ ayahnursikin@gmail.com
}

\begin{abstract}
The outbreak of the Covid-19 Pandemic that has been present since around March 2019 presents a new policy in the learning process in schools, including in high schools. Learning shifts from face-to-face to online or online learning. Schools have their own policies for the selection of online media that will be used in online learning. One of the online media used is Microsoft Teams which was chosen by SMKN 2 Salatiga for online learning. This study aims to describe the conditions and strategies used in distance learning's strategies (PJJ) by online learning In Islamic Religious Education at SMKN 2 SALATIGA. This study use a qualitative descriptive method through teachers and student's interviews, documentation and observation. The results of this study indicate that, first, the PJJ's planning on PAI subjects has been implemented through the making of RPP, training in Microsoft Teams applications and the provisions of infrastructure. Second, the implementation and participation of students in PJJ on PAI at SMKN 2 SALATIGA's subjects showed a high percentage. The implementation stages is done through the Microsoft Teams application. Third, the learning's evaluation was conducted using Google Form media, Microsoft Teams and Moodle. Remedial activities are given only during UAS.
\end{abstract}

Keywords: Distance Learnin;, Islamic Religious Education; Online Learning; Strategy 


\begin{abstract}
Abstrak
Wabah Pandemi Covid-19 yang hadir sejak sekitar Maret 2019 menghadirkan kebijakan baru dalam proses pembelajaran di sekolah, termasuk pada sekolah menengah. Pembelajaran beralih dari tatap muka menjadi pembelajaran online atau daring. Sekolah memiliki kebijakan tersendiri untuk pemilihan media online yang akan digunakan dalam pembelajaran daring. Salah satu media online yang digunakan adalah Microsoft Teams yang dipilih oleh SMKN 2 Salatiga untuk pembelajaran daringnya. Penelitian ini bertujuan untuk menguraikan kondisi dan strategi yang digunakan dalam PJJ dengan pembelajaran secara daring pada mata pelajaran PAI di SMKN 2 SALATIGA. Penelitian ini menggunakan metode kualitatif deskriptif melalui wawancara, dokumentasi dan observasi kepada guru PAI dan siswa. Hasil penelitian menunjukan bahwa, pertama, perencanaan PJJ online pada mata pelajaran PAI di SMKN 2 SALATIGA telah dilaksanakan melalui pembuatan RPP, pelatihan aplikasi Miccrosoft Teams dan penyediaan sarana prasarana. Kedua, pelaksanaan dan partisipasi siswa dalam PJJ pada mata pelajaran PAI menunjukkan persentase yang tinggi. Tahapan pelaksanaan dilakukan melalui aplikasi Microsoft Teams. Ketiga, evaluasi pembelajaran di dilaksanakan menggunakan media Google Form, Microsoft Teams dan Moodle. Kegiatan remidial diberikan hanya ketika UAS.
\end{abstract}

Kata kunci: Pembelajaran Jarak Jauh, Pendidikan Agama Islam, Pembelajaran Online; Strategi

\title{
A. Pendahuluan
}

Since the emergence of the Covid-19 outbreak, there has been a polemic in the world of education in implementing learning policies for each educational unit. Various strategies carried out under normal conditions have turned out to be difficult or even impossible to implement since the emergence of the Corona disease outbreak in Indonesia around March 2020. The outbreak caused the policy-making process of learning from what was originally in the form of face-to-face learning to distance learning (PJJ) conducted online (on the network) (Ika Firma Ningsih DP and Zulela 2021, 65).

Various policies have been launched by the government to support this distance learning. Starting from curriculum changes, subsidized learning quota assistance, training on learning methods, even to the preparation of learning media and the implementation of online learning. According to Moore, Dickson-Deane, \& Galyen (2011) Online learning is learning that uses the internet network with accessibility, connectivity, flexibility, and the ability to bring up various types of learning interactions. Online learning or e-learning can be said to be a flexible and most effective 
learning method because it is not limited by space and time, so most schools apply online learning as a strategy within the framework of PJJ, including SMKN 2 Salatiga.

Responding to policies decided by local governments or related education offices, One of them is the circular issued by the Minister of Education and Culture Number 3 of 2020 regarding the prevention of Covid-19 in Education Units and Number 36926/MPK.A/HK/2020 concerning online learning, schools also need to prepare themselves. The preparation is carried out using selected strategies which are then applied or implemented at various stages of learning. Starting from the planning stage, implementation, to evaluation to measure the achievement of learning objectives. Many consider the implementation of PJJ to be lighter than traditional learning. In fact, various obstacles often approach. Among them are the availability of infrastructure, quality and quantity of teachers who are not yet adequate. In fact, the use of e-learning media also has many obstacles, whether due to poor network connections or other factors (Ika Firma N.D.P. and Zulela 2021, 68-70).

Policies related to the implementation of PJJ in schools have a significant impact on the implementation of PAI learning. PAI's teachers are required to be able to develop learning strategies that must be adapted to the online PJJ media at the school. Moreover, the goal of PAI's learning is not only to achieve cognitive competence, but must be able to achieve affective and psychomotor competencies which are considered easier to implement when face-to-face compared to online. In fact, it is difficult to assess affective competence here given the absence of face-to-face activities with students.

This research was conducted to provide an overview of how the online PJJ planning, implementation and evaluation of PAI subjects at SMKN 2 Salatiga can be used as input as well as evaluation material for policies in online PJJ implementation on PAI subjects at SMKN 2 Salatiga and other schools so that Educational goals are fulfilled optimally so that it can be stated that education reaches its effectiveness.

\section{B. Pembahasan}

This study uses a descriptive qualitative approach. Qualitative research is considered as a research method that can be applied to examine the target situation as it is, where the researcher acts as a key tool; descriptive, data analysis is inductive; and its products prioritize meaning (Sugiyono 2019, 24). Various data were obtained by conducting interviews, observation and documentation.

This research was conducted in 2021 at SMKN 2 Salatiga as one of the schools that implement distance learning. As for the data collection technique by conducting 
interviews with 1 person of Curriculum's Head, 3 PAI teachers and 4 students of SMKN 2 SALATIGA. Meanwhile, observations were made in order to determine the condition of the facilities and infrastructure available at the school and documentation was conducted to obtain data on the condition and state of the research object and to obtain additional evidence of the implementation of the PJJ's strategy. While the measurement of the validity and reliability of the data in this study, using triangulation techniques that function to check the truth of the data in this study. Triangulation in trust testing is used as a check from all sources with several methods and time (Sugiyono 2019, 368). In order to analyze the data, the researcher used the Miles and Huberman model field analysis through data codification, data presentation and data verification (Afrizal 2017, 178-180).

\section{Distance Learning's Planning on PAI Subjects at SMKN 2 Salatiga}

Before carrying out learning, of course, careful planning is needed by the teacher so that the learning process can run smoothly. Harjanto stated that what is called planning is the first step that will lead to goals by determining various requirements with successful and efficient steps (Tatang Hidayat and Makhmud Syafe'i 2018, 195). From this statement, we can conclude that with planning, various components or conditions appear that are the conditions, which will support the achievement of an activity.

According to Siti Kusrini and colleagues, various stages of administrative planning include analyzing effective days, designing annual programs (prota) and semester programs (promes), designing syllabus, designing lesson plans (RPP), and designing assessments (Leny Marlina 2017, 7-8).

As for the planning that is directly related to the implementation of learning, it is contained in a device which we will here in after call the Learning Implementation Plan (RPP). In the RPP, various components must be stated that will support the achievement of a learning goal.

Regarding planning, in addition to administratively preparing tools in the form of one-sheet lesson plans, assessments, materials and assignments; PAI's teachers at SMKN 2 Salatiga also prepared various planning components in the form of media and supporting tools.

The various stages of planning the implementation of learning which are also components of the lesson plan include: 


\section{a. Determination of PAI's learning objectives}

Increasing faith and piety, building character or morality, and mastering worship practices are goals to be achieved by PAI's teachers. The learning objectives, in accordance with what was conveyed by Chabib Thoha and Abdul Mu'ti, that Islamic religious education aims to increase faith, understanding, appreciation, and application of religious teachings that will lead them to become human beings who have faith, piety and have akhlaqul karimah (Chabib Thoha and Abdul Mu'ti 1998, 179) .

Based on these references, through the results of the documentation, the specific learning objectives for each online learning at SMKN 2 Salatiga have been clearly stated in the lesson plans. However, the researcher saw that the learning objectives in the form of affective competence had not been listed in the lesson plans (RPP attached).

\section{b. Determination of learning's materials}

Teachers have their own strategies in terms of determining the material. The PAI's teacher of SMKN 2 SALATIGA divides and sorts the material in each semester, so that each semester covers aspects of aqidah, syari'ah, morals, and dates. As stated by Abdul Majid and Dian Andatani that the core teachings of Islam consist of aqidah, syari'ah, morality, Al-Qur'an-Hadith and dates (Abdul Majid and Dian Andatani 2004, 77). In addition, if the material in the children's handbook is incomplete; then the teacher will prepare or schedule the material needed from other sources. Although there is a reduction in the material, each teacher develops the material according to the learning's objectives.

\section{c. Selection of learning's methods}

The method of lecture, discovery learning as well as question-answer and discussion has been chosen by the PAI teacher of SMKN 2 SALATIGA through adjustments to the objectives or characteristics of the material to be given by the teacher. Each method has its own advantages. In line with what was conveyed by Tarmudji that lectures were able to condition the classroom situation and train student's listening and inference skills and the material could be conveyed evenly. On the other hand, Alipandie said that discussions can trigger the activeness of students so that it raises their patience and critical attitude (Mardiah Kalsum Nasution 2017, 14).

\section{d. Selection of learning media and tools}

Establishing learning media is something that needs to be planned from the start to minimize any obstacles in the learning process that will be implemented. Learning media in the form of Microsoft Teams, PPT, learning videos and LKPD that have been prepared by PAI's teachers of SMKN 2 SALATIGA, are expected to guide students' 
thinking processes as well as attract their interest in learning. This is in accordance with what was conveyed by Sadiman that the media has a function to provide learning information that will provoke ideas, interest and attention of students (Dyah Tri Wahyuningtyas and Raddin Nur Shinta 2017, 9).

Although the tools used are fairly simple, namely cellphones and laptops; however, this tool has a high efficiency for the online learning process. This tool has also been commonly used so that there are no obstacles in its operation. In accordance with Siddik's opinion that in using a tool, a teacher must know well the tool to be used so that it can function according to needs and objectives (Dja'far Siddik 2006, 143)

\section{e. Allocating study time}

As for the initial consideration of making lesson plans, the teacher needs to look at the available time allocation. The mismatch between the time provided, can make the application of learning methods less optimal. Therefore, time must be calculated carefully so that learning objectives are realized (Guntur Cahyono, Siti Asdiqoh 2020, 121). Regarding the allocation of time in SMKN 2 SALATIGA, learning which usually lasts forty-five minutes has been reduced to thirty minutes per hour.

Based on the results of interviews and observations, the allocation of PAI's learning time provided at SMKN 2 Salatiga is considered sufficient in this online learning. Ninety minutes of learning duration is sufficient for preliminary, core and closing activities. Moreover, if there is an assignment in it, the teacher gives a long grace period for the completion of the assignment.

\section{f. Selection of learning resources}

As for learning resources in SMKN 2 Salatiga, textbooks are the main learning resources. Besides, it also uses modules, learning videos, and PPT. The learning resources used at SMKN 2 Salatiga are quite complete, not only from physical textbooks, but also pdf textbooks that can be read at any time, and use other references to complement and support understanding the material. Teachers not only provide visual learning resources, but also learning resources that have been equipped with audio, for example, PPT and learning videos; so that students' audio-visuals are balanced and learning is easier to remember and understand, besides that it can also increase students' interest in learning. As stated by Sulfemi and Zulaicha that audio-visual media in presenting learning material, will be captured by sight and hearing, which is useful for conditioning students to achieve cognitive, affective and psychomotor competencies (Sulfemi, et al. 2018, 232-245).

Based on the discussion above, it can be concluded that schools and teachers have prepared well-planned PJJ online using Microsoft Teams, teaching tools and 
learning media. All learning components contained in the lesson plan have also been designed in such a way with the hope that the learning objectives can be achieved.

\section{Implementation of Distance Learning in PAI Subjects at SMKN 2 Salatiga}

PAI learning activities at SMKN 2 Salatiga are carried out through several stages, including preparing materials, opening applications, entering M. Teams' class, entering the announcements column, greeting students, habituation to pray before starting learning, attendance by active chat with students, giving learning instructions and conveying learning objectives, sharing material, either with modules, video links, or PPT uploaded in the material column, conducting $\mathrm{M}$. Teams group chats to encourage and motivate students, conduct questions and answers and provide explanations or instructions if there are students who are lacking can understand and finally close the lesson.

The learning activities are contained in three stages, namely preliminary activities, core activities and closing activities.

\section{a. Preliminary activities}

Hamzah B. Uno explained that the preliminary activity is a part that has an important meaning in order to provoke students' interest in the material to be studied. Various ways can be done to foster student motivation, for example by providing parables in the form of pictures in real life or conveying the benefits directly from studying the material (Hamzah 2014, 63).

In the preliminary activity, the PAI's teacher at SMKN 2 Salatiga greets students, gets into the habit of praying before starting the lesson, attends an active chat with students, and provides learning instructions and conveys learning objectives. In fact, other strategies are also carried out by PAI's teachers at SMKN 2 Salatiga. For example, students are asked to work on questions as a requirement for attendance as presented by SW1(one of student's respondent). SW1 said, "On a predetermined schedule, the PAI's teacher opens a class containing questions that must be done by students for attendance requirements. So students are required to work on these questions as a condition for attendance. (Results of interview with SW1, 18 February 2021)."

\section{b. Core activities}

The next step is to enter the core activity. At this stage, the PAI's teacher at SMKN 2 Salatiga distributes material, it can be in the form of modules, videos, or PPT that is uploaded to the material column, conducts questions and answers and provides explanations. This is in line with the opinion of Hamzah who called it the term 
information delivery. At this stage, the teacher provides stimulation regarding the content of the material to be given, while students respond to it (Hamzah B. Uno 2014, $63)$.

When delivering the material, the SMKN 2 Salatiga's PAI teacher has their own strategy. In addition to dividing and sorting the material in each semester, so that each semester covers all aspects; PAI's teachers also prepare the necessary materials from other sources. Not only that, PAI materials are also delivered in sequence according to the chapters in the student textbooks.

In addition, the teacher inserts a problem that can be classified as problem-based learning that will bring out student creativity. In line with what was conveyed by Guntur, that problem based learning is learning that makes students the center of activities by presenting a real case and then looking for a solution by students, thereby enhancing the creativity of these students (Guntur Cahyono and Siti Asdiqoh 2020, 11).

For the use of menus in M. Teams, not all of them are used. However, most of the content in the M. Teams application has been mastered, including announcements, assignments, file uploads, chat. Meanwhile, meet has not been used because it is related to the limitations of student's internet services. Meanwhile, teachers cannot use the PAI's announcements column specifically because in one class not all of them are Muslim. Therefore, PAI's teachers enter announcements in the general column; so that every announcement that is posted, will automatically appear on the screens of other subject teachers.

Strategies of SMKN 2 Salatiga's PAI teachers in the use of media is quite good. In addition to paying attention to the cost aspect, it also considers the ease of use and suitability with the learning method. As revealed by Hamzah, although there are various media with a myriad of functions, a teacher can choose based on certain considerations. Among them are cost, compatibility with learning methods and student characteristics and practicality (Syafruddin Nurdin 2003, 97).

Through the use of Microsoft Teams, students can actively respond to the learning delivered by the teacher. In addition, the learning videos provided also make it easier for students to understand the material presented because it is displayed in audio form which is provided with interesting visualizations.

Several learning methods are used by SMKN 2 Salatiga's PAI teachers. Among them are lectures through learning videos or PPT, discovery learning, question and answer via chat $\mathrm{M}$. Teams or WA, and online discussions by sending modules or materials first. These methods were chosen to build students' cognitive abilities. In 
addition, teachers also choose methods that will build their psychomotor abilities. For example, making videos of praying, praying sunnah, reciting the Holly Qur'an or others.

Several important factors in the use of teaching methods according to Ambo Ende Abdullah are in accordance with the learning objectives and conditions of students, learning activities are suitable for the environment, and lessons are well coordinated (Syafruddin Nurdin 2003, 102). In line with the opinion of Ambo Ende Abdullah, the learning method used at SMKN 2 Salatiga has been adapted to the learning objectives to be achieved. In addition, it has also been adapted to the conditions of students so that learning can be well coordinated.

In addition, the teacher gives a number of questions to students as a condition of attendance. This is also an effective method to be able to provoke student activity in learning. As stated by Syafruddin, one way that can be used to involve students before teaching is to generate new interest in participating in activities by asking questions that explore students' thoughts (Syafruddin Nurdin 2003, 97).

According to Nurhadi, in a contextual approach, the real world tries to be displayed in the classroom, students are encouraged to be able to make connections between their knowledge and its implementation, students gradually gain knowledge and skills from the environment and from the process of building themselves (Muhammad Fathurrohman 2018, 2). In delivering learning, PAI's teachers at SMKN 2 Salatiga have used a contextual approach, so that children will be able to connect the knowledge they have acquired with real situations. This will be able to build students' critical and innovative attitude.

In addition, the learning provided at SMKN 2 Salatiga uses a student-centered scientific method so that the teacher acts as a facilitator and demands student activity. Muhammad Fathurrohman conveyed several characteristics of scientific learning including being centralized in students, the role of process skills in building concepts, the role of cognitive processes and the formulation of simple learning objectives (Muhammad Fathurrohman 2018, 21-22).

\section{c. Closing Activities}

As for closing activities, SMKN 2 Salatiga's PAI teachers provide explanations or instructions if there are students who are unable to understand and close the lesson. This is in line with what Hamzah said, namely to end learning, a teacher can provide feedback, assess student competence or provide conclusions and follow-up (Hamzah 2014, 64). 
Based on the results of interviews with SMKN 2 Salatiga's PAI teacher, researchers can conclude that the stages of implementing learning in the form of preliminary, core and closing activities have been quite complete using media in the form of the Microsoft Teams application.

Regarding the form of SMKN 2 Salatiga's student participation, it can be seen from various things. Among them are activity on the platform used, collecting student assignments and working on assessments. Curriculum department said that all students can access and participate in PJJ properly. Hamzah said that the active role of students will play an important role in the learning discussion (Hamzah 2014, 35). Students of SMKN 2 Salatiga can be said to be active in online learning activities during PJJ, as evidenced by the recap of student access in the M. Teams application, active chat and task collection and assessment work.

\section{Evaluation of Distance Learning on PAI Subjects at SMKN 2 Salatiga}

\section{a. Learning Evaluation Stages}

There are several important things to consider in planning an evaluation. The evaluation of PAI's learning at SMKN 2 Salatiga consists of formative and submative tests. The stages are formative tests in the form of compiling grids, compiling questions, and uploading quizzes to M. Teams or Google Form. While the submative tests are in the form of compiling grids, compiling questions, and uploading quizzes to Moodle.

In general, researchers can conclude that the stages of evaluation planning (formative or submative) of PAI learning in PJJ can be seen in the figure 1.

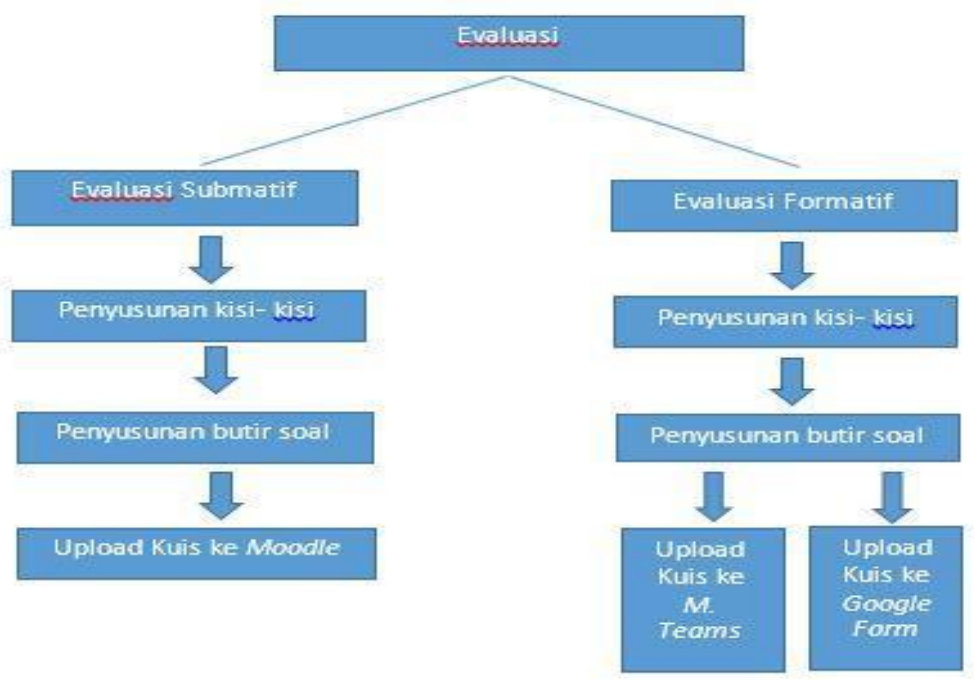

Figure 1. Stages of Planning for Learning Evaluation at SMKN 2 Salatiga 
According to Zainal Arifin, the stages in the evaluation of learning include determining the purpose of the assessment, identifying learning abilities and outputs, compiling grids, developing a list of questions, and conducting experiments and analyzing questions, as well as making improvements and rearranging new questions (Zainal Arifin 2016, 91 -102). So, the researcher concludes that evaluation activities are not only limited to making grids, questions and implementation. However, it is also necessary to analyze the questions and follow up on the analysis. Evaluation activities at SMKN 2 Salatiga have been carried out according to the agenda that has been made, but we do not see any form of experimentation, problem analysis and improvement and rearrangement of new questions in the evaluation stage.

On the other hand, after completing a series of learning evaluation programs; the teacher also uploads the scores to SIKADU, as a form of evaluation activity report that can be seen by students and guardians of students as well as various other related parties. In line with what Atmaja said, the evaluation results can be used by educators and students. In addition, the school, supervisors, and guardians of students also have the right to receive it. All of this is done in order to find out the developments that occur in students (Nanda Pramana Atmaja 2016, 47).

\section{b. Types of PAI's Learning Evaluation in online's PJJ}

Teachers can choose various types of evaluations that will be used to assess learning outcomes in carrying out evaluations. Regarding the type of evaluation applied, GA2 ( one of teacher's respondent) stated, "Affective scores are taken through teacher assessments of students' communication ethics with teachers online, cognitive with daily assessment tests and assignments, psychomotor with practical assignments(Results of interview with GA2, February 16, 2021)."

PAI's subjects are required to meet the three aspects of the assessment, namely affective, cognitive and psychomotor aspects. Atmaja revealed that the three domains, namely affective, cognitive and psychomotor are always related to the learning process. Atmaja added that the attitude assessment was carried out through observing the attitudes of students in the learning environment which started from a reaction to the existing stimulus. The targets of attitude assessment in learning include students' attitudes towards subject matter, teachers, learning processes, and values or norms related to lesson content (Nanda Pramana Atmaja 2016, 125-127). In line with this opinion, PAI's teachers at SMKN 2 Salatiga take an attitude assessment through observing students' communication ethics towards teachers during online learning; cognitive with daily assessment tests and assignments, psychomotor with practice assignments. As for the form of assessment in terms of cognitive by giving daily assessment tests and assignments, psychomotor by giving practice assignments, for 
example making videos of the performing of funeral prayers and writing thematic verses. Technically, the assessment is done online.

Daily assessments, PTS and UAS SMKN 2 Salatiga in the form of multiple choice which are presented online, provide a lot of convenience and speed for teachers in terms of correction. As stated by Atmaja, multiple choice questions have advantages. Among them are the material being tested more broadly, all levels of the cognitive domain can be contained in it, can be tested on many students, have a high objectivity value, and are easier and faster to assess (Nanda Pramana Atmaja 2016, 101-102).

The form of assessment carried out by PAI's teachers in SMKN 2 Salatiga is in the form of oral and written assessments. In writing, for example working, orally by reading or memorizing pieces of the verses of the Qur'an; where assignments are delivered via $\mathrm{M}$. Teams.

The types and forms of online assessments at SMKN 2 Salatiga can be seen from the figure 2 .

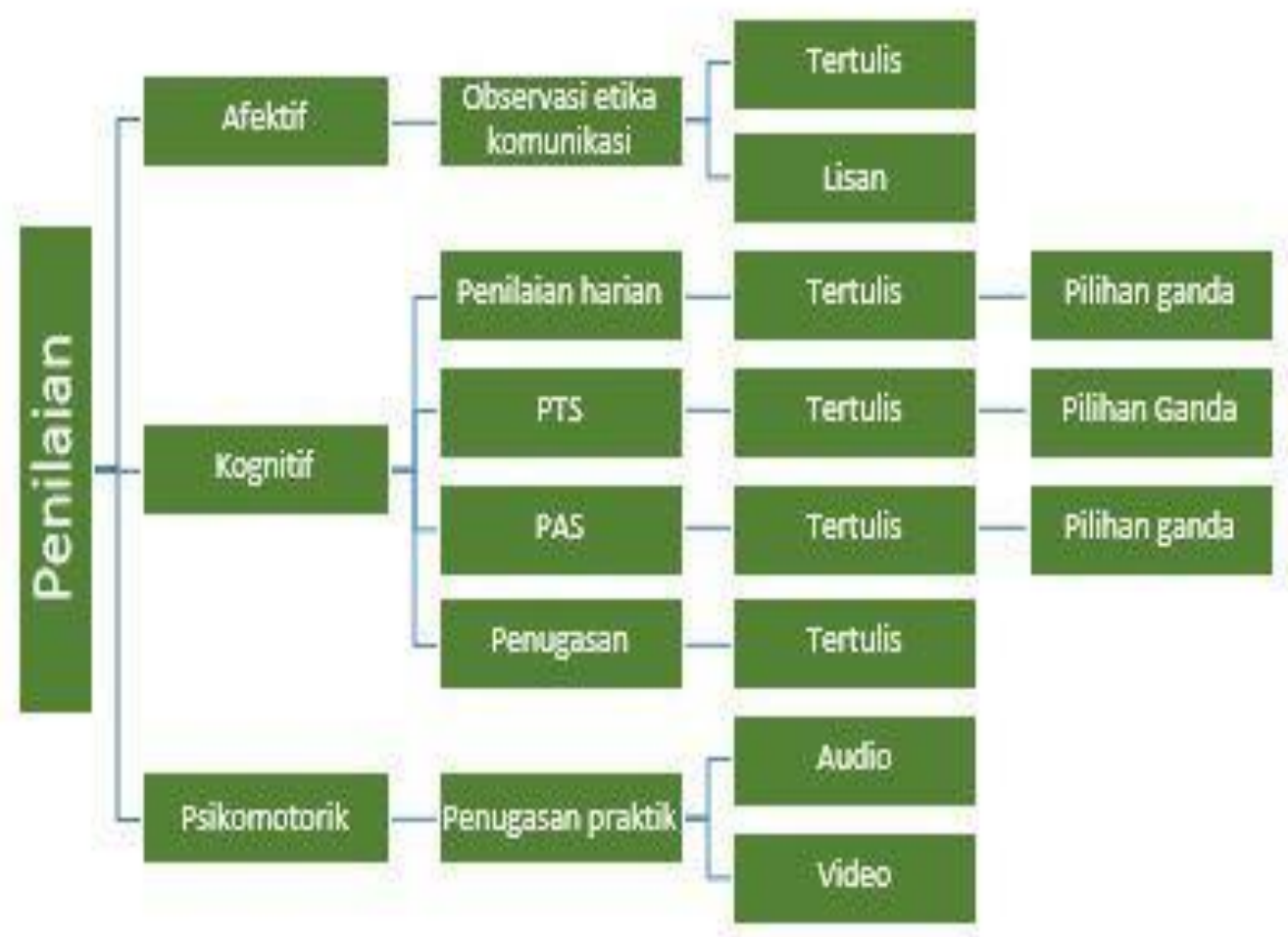

Figure 2. Types and Forms of Learning Evaluation at SMKN 2 Salatiga 


\section{c. Implementation of Remedial and Enrichment Programs}

After carrying out the assessment, a remedial program was held for students who did not complete and an enrichment program for students who had completed the minimum completeness criteria (KKM). Daily assessment and PTS without remedial and enrichment. However, for PAS there are remedial and enrichment

Of course, a teacher must identify students who are classified as remedial in conducting remedial programs. In addition, the teacher needs to identify each of the incompleteness of the questions that the students are working on. Before giving a reassessment, teachers need to conduct re-learning so that students complete according to the desired competencies. As stated by Fakihuddin, remedial teaching is an effort to improve student learning outcomes in accordance with the goals that have been set. In its implementation, students must follow various paths in a coherent manner by identifying various difficulties and causes of difficulties experienced by students (Fakihuddin 2007, 13).

According to the results of the study, researchers can conclude that SMKN 2 Salatiga's PAI teachers have carried out learning evaluations, along with their follow-up in the form of remedial and enrichment. The learning evaluation is in the form of oral and written which includes cognitive, affective, and psychomotor aspects. Evaluation is done through quizzes uploaded in Microsoft Teams, Google Forms and Moodle. Meanwhile, remedial programs that should be given when re-learning has been carried out cannot be carried out properly, only in the form of providing opportunities to work on questions again or remedial, during the end of semester assessment only.

\section{Simpulan}

The government's policy of imposing distance learning during the Covid-19 pandemic, provides space for educators to respond. One of them is to bring out the creativity of educators to set learning strategies so that learning objectives can be achieved. In carrying out distance learning activities, PAI's teachers at SMKN 2 Salatiga have strategies at the planning, implementation and evaluation stages of learning. PJJ's planning for PAI subjects at SMKN 2 Salatiga has been carried out through making lesson plans, training on the Microsoft Teams application and providing infrastructure. The implementation and participation of students in PJJ in PAI subjects at SMKN 2 Salatiga shows a high percentage. The implementation stages are carried out through the Microsoft Teams application. While the evaluation of learning at SMKN 2 Salatiga was carried out using Google Form, Microsoft Teams and Moodle media. Remedial activities are given only during UAS. 


\section{DAFTAR PUSTAKA}

Afrizal. 2017. Metode Penelitian Kualitatif ( Sebuah Upaya Mendukung Penggunaan Penelitian Kualitatif dalam Berbagai Disiplin Ilmu). Depok: Rajawali Pers.

Arifin, Zainal. 2016. Evaluasi Pembelajaran. Bandung: Remaja Rosdakarya.

Atmaja, Nanda Pramana. 2016. Buku Super Lengkap Evaluasi Belajar- Mengajar. Yogyakarta: Diva Press.

Cahyono, G. \& Asdiqoh, S. 2020. Metodologi Pembelajaran Pendidikan Agama Islam. Sukoharjo: Oase Pustaka.

Fakihuddin, L. 2007. Pengajaran Remidial dan Pengayaan. Jayapura: Bayumedia Publising.

Fathurrohman, Muhammad. 2018. Mengenal Lebih Dekat Pendekatan dan Model Pembelajaran. Yogyakarta: Kalimedia.

Hidayat, T. \& Syafe'i, M. 2018. "Filsafat Perencanaan dan Implikasinya dalam

Perencanaan Pembelajaran Pendidikan Agama Islam di Sekolah." Lentera Pendidikan Jurnal Ilmu Tarbiyah dan Keguruan 21(2): 188-205.

http://journal.uinalauddin.ac.id/index.php/lentera_pendidikan/article/view/188-205.

Majid, Abdul. 2014. Strategi Pembelajaran. Bandung: Remaja Rosdakarya.

Marlina, L. 2017. "Perencanaan Pembelajaran Pendidikan Anak Usia Dini." Raudhatul Athfal: Jurnal Pendidikan Islam Anak Usia Dini 1(2).

http://jurnal.radenfatah.ac.id/index.php/raudhatulathfal/article/view/2679.

Nasution, M. K. 2017. "Penggunaan Metode Pembelajaran dalam Peningkatan Hasil Belajar Siswa." STUDIA DIDAKTIKA:Jurnal Ilmiah Bidang Pendidikan 11(1): 916.

http://www.jurnal.uinbanten.ac.id/index.php/studiadidaktika/article/view/515.

Nurdin, Syafruddin. 2003. Guru Profesional dan Implementasi Kurikulum. Jakarta: Ciputat Press.

Primasari, I.F.N.D \& Zulela. 2021. Kendala Pembelajaran Jarak Jauh (PJJ) secara Online Selama Masa Pandemik Covid-19 di Sekolah Dasar. JIKAP PGSD: Jurnal Ilmiah Ilmu Kependidikan 5(1): 64-73.

https://ojs.unm.ac.id/JIKAP/article/view/16820.

Siddik, Dja'far. 2006. Ilmu Pendidikan Islam. Bandung: Citapustaka Media.

Sugiyono. 2019. Metode Penelitian Kuantitatif Kualitatif dan R\&D. Bandung: Alfabeta.

Thoha, C. \& Mu'ti, A. 1998. PBM PAI di Sekolah Eksistensi dan Proses Belajar Mengajar Pendidikan Agama Islam. Yogyakarta: Pustaka Pelajar. 
Sulfemi, Bagja, W. \& Desmiati Z. 2019. "Model Pembelajaran Missouri Mathematics Project Berbantu Media Relief Experience dalam Meningkatkan Hasil Belajar Siswa." PENDAS MAHAKAM: Jurnal Pendidikan dan Pembelajaran Sekolah Dasar 3(3): 232-245.

http://103.8.79.252/index.php/pendasmahakam/article/view/269.

Uno, Hamzah B. 2014. Model Pembelajaran: Menetapkan Proses Belajar Mengajar yang Kreatif dan Inovatif . Jakarta: Bumi Aksara.

Wahyuningtyas, D.T. \& Shinta, R. N. 2017. "Pelatihan Media Pembelajaran Matematika berdasarkan Kurikulum 2013 bagi Guru Sekolah Dasar di Gugus 9 Kecamatan Sukun Malang." Jurnal Dedikasi 14: 08-11. https://ejournal.umm.ac.id/index.php/dedikasi/article/view/4293. 
